\title{
SISTEM TEMU KEMBALI INFORMASI UNTUK PENCARIAN JUDUL TUGAS AKHIR BERBASIS KATA KUNCI
}

\author{
B. Very Christioko ${ }^{1}$, April Firman Daru ${ }^{2}$ \\ 1, dan 2 Program Studi Teknik Informatika Universitas Semarang \\ ${ }^{1}$ very@usm.ac.id, ${ }^{2}$ firman@usm.ac.id
}

\begin{abstract}
Abstrak
Kesamaan atau kemiripan judul pada saat mahasiswa mengambil mata kuliah Tugas Akhir (TA) dapat mungkin terjadi. Hal ini merupakan masalah yang serius dalam penelitian bagi mahasiswa saat mengerjakan TA atau skripsi.Saat ini di Fakultas TIK, data judul TA yang sudah selesai masih hanya disimpan ke dalam sebuah basis data pada saat pengajuan dan belum digunakan sebagai sumber rujukan untuk mengecek kesamaan atau kemiripan. Untuk itu dibutuhkan sebuah alat untuk menemukan informasi judul-judul yang sudah ada pada database menggunakan mesin pencari. Dikarenakan mesin pencari merupakan bentuk praktek dari penerapan teknik temu kembali informasi pada koleksi text dengan skala besar maka perlu adanya sebuah mesin pencari judul Tugas Akhir pada Fakultas TIK yang menerapkan teknik temu kembali informasi dengan model Boolean retrieval.
\end{abstract}

Kata Kunci : Boolean retrieval, Mesin Pencari, Teknik temu kembali.

\begin{abstract}
The similarity or resemblance of the title at the time students take the Final Task subject may be possible. This is a serious problem in research for students while working on Final Task or minithesis. Currently in the Faculty of Information Technology and Communication, the completed Final Task title data is still only stored into a database at the time of submission and has not been used as a referral source to check for similarities or similarities. For that we need a tool to find information titles that already exist in the database using search engines. Because the search engine is a form of practice of applying information retrieval techniques on large-scale text collections it is necessary to have a search engine title Final Task on the Faculty of Information Technology and Communication that apply information retrieval techniques with Boolean retrieval model.
\end{abstract}

Keywords: Boolean retrieval, Search engine, Technique of Retrieval

\section{Latar Belakang}

Kualitas tertinggi dari sebuah karya tulis diukur dari orisinalitas atau keaslian. Keaslian yang diamaksudkan disini lebih pada kejujuran dalam mengemukakan tulisannya. Tidak semua tulisan dalam karya ilmiah adalah berasal dari diri sendiri melainkan milik orang lain yang berupa kata, kalimat, paragraph, ide, gagasan atau pendapat, maka secara etika ilmiah kita wajib mencantumkan sumber dengan jujur dan objektif dari mana mendapatkan kutipan tersebut, bila ini tidak dilakukan maka akan memunculkan masalah plagiasi (Mulyana, 2010).

Plagiasi merupakan masalah serius dalam penelitian termasuk bagi mahasiswa saat mengerjakan mata kuliah Tugas Akhir (TA) atau skripsi.TA merupakan mata kuliah yang harus diambil mahasiswa sebelum lulus kuliah. Untuk dapat memulai mengerjakan TA mahasiswa harus mengajukan judul yang tidak memiliki kesamaan atau kemiripan dengan judul TA yang sudah ada untuk menghindari Plagiasi. Permasalahan yang terjadi adalah belum adanya sistem untuk melakukan deteksi kesamaan atau kemiripan judul TA. Saat ini pengelolaan data judul Tugas Akhir masih hanya disimpan ke dalam sebuah basis data pada saat pengajuan dan belum digunakan sebagai sumber rujukan untuk mengecek kesamaan atau kemiripan.

Perkembangan internet saat ini menjadikan kebutuhan untuk menemukan informasi secara cepat dan tepat semakin tinggi.Kebutuhan ini mendorong orang-orang di perusahaan maupun universitas menggunakan sebuah mesin pencari untuk membantu menemukan informasi baik berupa text, gambar maupun video.Mesin pencari merupakan bentuk praktek dari penerapan teknik temu kembali informasi pada koleksi text dengan skala besar. Komponen dalam mesin pencari mendukung 2 (dua) fungsi utama yaitu indexing process dan query process, indexing process membangun struktur yang memungkinkan pencarian, sedang query process menggunakan struktur-struktur tersebut dan permintaan pengguna untuk menghasilkan daftar peringkatdokumen atau teks (W. Bruce Crof, 2015). Boolean retrieval merupakan salah satu model temu kembali informasi yang digunakan pada mesin pencari. Model ini juga biasa dikenal dengan istilah exact-match retrieval dikarenakan dokumen atau teks akan ditemukan jika benar-benar sesuai dengan spesifikasi pencarian (W. Bruce Crof, 2015). Model Boolean retrieval ini sesuai 
digunakan untuk melakukan pencarian judul-judul penelitian maupun karya ilmiah seperti yang sudah dilakukan oleh Christioko (2012).

Oleh karena itu mesin pencari untuk menemukan judul TA menjadi sebuah kebutuhan dengan tujuan menghindari kesamaan atau kemiripan.

\section{KAJIAN PUSTAKA}

\subsection{Plagiasi Tugas Akhir}

Mulyana (2010) menyatakan bahwa plagiasi dalam dunia akademik (khususnya dosen dan mahasiswa) sangat mungkin terjadi apabila etika ilmiah dalam mencantumkan sumber dengan jujur dan objektif dimana kutipan-kutipan berupa kata, kalimat, paragraph, ide, gagasan, atau pendapat yang merupakan milik orang lain tidak dilakukan. Maka civitas akademika diharapkan memegang teguh etika akademik yang berlaku. Berikut merupakan hasil penelitian yang dilakukan Mulyana tentang jenis plagiarism Tugas Akhir Skripsi (TAS) Mahasiswa.

Tabel 1. Jenis Plagiarisme TAS Mahasiswa

\begin{tabular}{|l|l|l|}
\hline \multicolumn{1}{|c|}{ KasuS } & \multicolumn{1}{c|}{$\begin{array}{c}\text { Jenis } \\
\text { Plagiarisme }\end{array}$} & \multicolumn{1}{c|}{$\begin{array}{c}\text { Tindakan } \\
\text { Pencegahan }\end{array}$} \\
\hline Plagiarisme & Duplikasi judul & Mengembalikan usulan \\
Skripsi & Duplikasi substansi & TAS dan atau merevisi \\
& Duplikasi teori & Mengharuskan \\
& Duplikasi data & pengutipan primer \\
& Duplikasi referensi & Membatalkan karya tulis \\
\hline
\end{tabular}

Plagiarisme dalam bentuk duplikasi judul menyangkut kesamaan atau kemiripan judul dari karya tulis mahasiswa lain. Artinya, beberapa proposal dan atau skripsi dapat mempunyai kesamaan atau kemiripan dalam hal judul, topik, data, dan kajian teori.

\subsection{Mesin Pencari}

Sebuah mesin pencari adalah penerapan praktis dari teknik pengambilan informasi untuk koleksi teks dengan skala besar.Istilah "Mesin Pencari" awalnya digunakan untuk mengacu ke perangkat keras khusus untuk pencarian teks.Mulai pertengahan tahun 1980-an, secara bertahap mulai merujuk ke "information retrieval system" sebagai nama dari perangkat lunak yang melakukan proses membandingkan dokumen dan menghasilkan daftar ranking dokumen (Crof, 2015).

\subsection{Arsitektur Mesin Pencari}

Sebuah arsitektur dari mesin pencari didesain untuk memastikan bahwa sistem akan memuaskan kebutuhan atau tujuan (Crof, 2015). Dua tujuan utama dari mesin pencari adalah:

1. Effectiveness (quality),kemampuan uuntuk mengambil kumpulan dokumen yang paling relevan dalamm sebuah permintaan.

2. Efficiency (speed), kemampuan untuk memproses permintaan dari user secepat mungkin.
Komponen mesin pencari mendukung dua fungsi utama, yang biasa disebut dengan indexing process dan query process.Indexing process membangun struktur yang memungkinkan untuk pencarian, dan query process menggunakan struktur tersebut dan permintaan pengguna untuk memproduksi daftar ranking dokumen. Gambar berikut menunjukkan bagan dari indexing process.

Komponen utama dari queryprocess adalah userinteraction, ranking, dan evaluation. Komponen user interaction menyediakan antarmuka antara pengguna yang melakukan pencarian dan mesin pencari.Tugas utama komponen ini adalah menerima query pengguna dan mengubahnya ke bentuk index terms. Tugas lain adalah mengambil daftar dokumen terangking dari mesin pencari dan mengatur hasilnya untuk dilihat oleh pengguna. Komponen ranking merupakan inti dari mesin pencari. Komponen ini membawa query dari pengguna yang sudah diterjemahkan dan menciptakan daftar ranking dari dokumen menggunakan basis skor pada model temu kembali. Sedangkan komponen evaluation bertugas untuk mengukur dan memonitor effectiveness dan efficiency.

\subsection{Temu Kembali Informasi (Information \\ Retrieval)}

Menurut Jansen, B. J. and Rieh, S. (2010) Sebuah objek adalah sebuah entitas yang diwakili oleh informasi dalam basis data. User queries dicocokkan dengan database informasi. Hasil information retrieval(IR) yang dikembalikan mungkin sesuai dengan query, sehingga iasanya hasilnya diperingkat. Peringkat ini berasal dari hasil perbedaan kunci pencarian informasi pencarian dibandingkan dengan mencari database. Sedangkan pengertian IR menurut Manning et al, (2008) adalah "Information retrieval (IR) is finding material (usually documents) of an unstructured nature (usually text) that satisfies an information need from within large collections (usually stored on computers)". Dapat disimpulkan bahwa IR adalah proses menemukan materi yang biasanya dokumen dari data yang tidak terstruktur yang memenuhi kebutuhan informasi dari sebuah kumpulan koleksi yang tersimpan pada komputer. Berikut skema konsep dasar dari sebuah IR

Sistem Temu-Balik Informasi (Information Retrieval) digunakan untuk menemukan kembali informasi-informasi yang relevan terhadap kebutuhan pengguna dari suatu kumpulan informasi secara otomatis. Salah satu aplikasi umum dari sistem temu kembali informasi adalah search-engine atau mesin pencarian yang terdapat pada jaringan internet. Pengguna dapat mencari halaman-halaman Web yang dibutuhkannya melalui mesin tersebut.

Ukuran efektifitas pencarian ditentukan oleh precision dan recall. Precision adalah rasio jumlah dokumen relevan yang ditemukan dengan total jumlah dokumen yang ditemukan oleh search-engine. 
Precision mengindikasikan kualitas himpunan jawaban, tetapi tidak memandang total jumlah dokumen yang relevan dalam kumpulan dokumen.

Precision $=\frac{\mid\{\text { relevant documents }\} \cap\{\text { documents retrieved }\} \mid}{\mid\{\text { documents retrieved }\} \mid}$

Recall adalah rasio jumlah dokumen relevan yang ditemukan kembali dengan total jumlah dokumen dalam kumpulan dokumen yang dianggap relevan.

Recall $=\frac{\mid\{\text { relevant documents }\} \cap\{\text { documents retrieved }\} \mid}{\mid\{\text { relevant documents }\} \mid}$

Dalam Information Retrieval, mendapatkan dokumen yang relevan tidaklah cukup. Tujuan yang harus dipenuhi adalah bagaimana mendapatkan dokumen relevan dan tidak mendapatkan dokumen yang tidak relevan. Tujuan lainnya adalah bagaimana menyusun dokumen yang telah didapatkan tersebut ditampilkan ${ }^{\text {terurut }}$ dari dokumen yang memiliki tingkat relevansi lebih tingi ke tingkat relevansi rendah. Penyusunan dokumen terurut tersebut disebut sebagai perangkingan dokumen. Model Ruang Vektor dan Model Probabilistik adalah 2 model pendekatan untuk melakukan hal tersebut.

Model ruang vektor dan model probabilistik adalah model yang menggunakan pembobotan kata dan perangkingan dokumen. Hasil retrieval yang didapat dari model-model ini adalah dokumen terangking yang dianggap paling relevan terhadap query.Terdapat beberapa cara atau metode dalam melakukan pembobotan kata pada metode TF-IDF, yaitu melalui skema pembobotan query dan dokumen. Dalam model ruang vektor, dokumen dan query direpresentasikan sebagai vektor dalam dalam ruang vektor yang disusun dalam indeks term, kemudian dimodelkan dengan persamaan geometri. Sedangkan model probabilistik membuat asumsi-asumsi distribusi term dalam dokumen relevan dan tidak relevan dalam order estimasi kemungkinan relevansi suatu dokumen terhadap suatu query.

\subsection{Model Boolean Retrieval (exact-matchretrieval)}

Model Boolean retrieval adalah model temu kembali informasi yang mengekspresikan query menggunakan bentuk ekspresi Boolean seperti and, or, dan not (Manning et al, 2008). Dalam model ini diperlukan sebuah proses pengindekan sehingga akan membentuk sebuah matrik term-document incidence. Pengindekan adalah operasi offline untuk mengumpulkan data yang berisi kata yang terdapat pada teks, sehingga pada saat pencarian kita hanya perlu mengakses index. Contoh berikut adalah matrik dari kumpulan dokumen berupa karya dari Shakespeare. Elemen Matrix (t, d) bernilai 1 jika peran pada kolom d mengandung kata pada baris t, bernilai 0 jika sebaliknya.

\begin{tabular}{l|llllll} 
& $\begin{array}{l}\text { Antony } \\
\text { and } \\
\text { Cleopatra }\end{array}$ & $\begin{array}{l}\text { Julius } \\
\text { Caesar }\end{array}$ & $\begin{array}{l}\text { The } \\
\text { Tempest }\end{array}$ & Hamlet & Othello & Macbeth \\
\hline Antony & 1 & 1 & 0 & 0 & 0 & 1 \\
Brutus & 1 & 1 & 0 & 1 & 0 & 0 \\
Caesar & 1 & 1 & 0 & 1 & 1 & 1 \\
Calpurnia & 0 & 1 & 0 & 0 & 0 & 0 \\
Cleopatra & 1 & 0 & 0 & 0 & 0 & 0 \\
mercy & 1 & 0 & 1 & 1 & 1 & 1 \\
worser & 1 & 0 & 1 & 1 & 1 & 0 \\
$\cdots$ & & & & & & \\
\hline
\end{tabular}

Gambar1. Contoh matrik term-document incidence

Selanjutnya model ini memproses query dari pengguna yang menggunakan ekspresi Boolean yaitu AND, OR dan NOT. Berikut contoh pemrosesan query oleh model Boolean Retrieval.

\section{Query: "Brutus AND Caesar AND NOT Calpunia"}

Tahap 1: Index Awal

\begin{tabular}{l|llllll|} 
& $\begin{array}{l}\text { Antony } \\
\text { and } \\
\text { Cleopatra }\end{array}$ & $\begin{array}{l}\text { Julius } \\
\text { Caesar }\end{array}$ & $\begin{array}{l}\text { The } \\
\text { Tempest }\end{array}$ & Hamlet & Othello & Macbeth \\
\hline Antony & 1 & 1 & 0 & 0 & 0 & 1 \\
Brutus & 1 & 1 & 0 & 1 & 0 & 0 \\
Caesar & 1 & 1 & 0 & 1 & 1 & 1 \\
Calpurnia & 0 & 1 & 0 & 0 & 0 & 0 \\
Cleopatra & 1 & 0 & 0 & 0 & 0 & 0 \\
mercy & 1 & 0 & 1 & 1 & 1 & 1 \\
worser & 1 & 0 & 1 & 1 & 1 & 0 \\
$\ldots$ & & & & & & \\
\hline
\end{tabular}

Tahap 2: Operasi NOT dijalankan

\begin{tabular}{l|llllll|} 
& $\begin{array}{l}\text { Antony } \\
\text { and } \\
\text { Cleopatra }\end{array}$ & $\begin{array}{l}\text { Julius } \\
\text { Caesar }\end{array}$ & $\begin{array}{l}\text { The } \\
\text { Tempest }\end{array}$ & Hamlet & Othello & Macbeth \\
\hline Antony & 1 & 1 & 0 & 0 & 0 & 1 \\
Brutus & 1 & 1 & 0 & 1 & 0 & 0 \\
Caesar & 1 & 1 & 0 & 1 & 1 & 1 \\
$\neg$ Calpurnia & 1 & 0 & 1 & 1 & 1 & 1 \\
Cleopatra & 1 & 0 & 0 & 0 & 0 & 0 \\
mercy & 1 & 0 & 1 & 1 & 1 & 1 \\
worser & 1 & 0 & 1 & 1 & 1 & 0 \\
$\cdots$ & & & & & & \\
\hline
\end{tabular}

Tahap 3: Perhitungan operasi AND

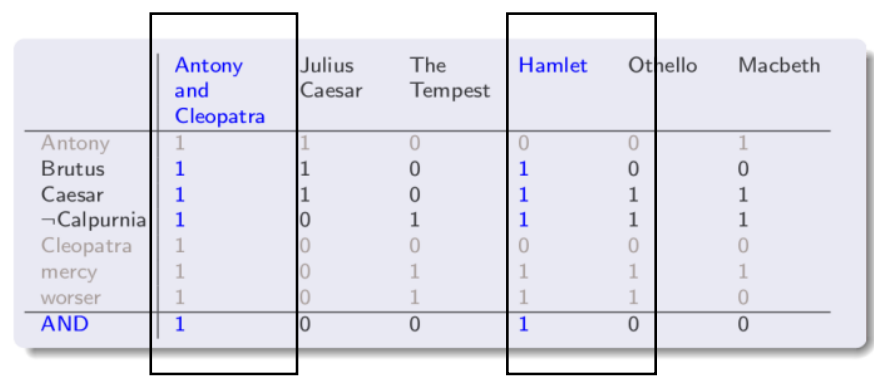

Hasil dari perhitungan operasi AND diatas mengembalikan dokumen "Antony and Cleopatra" dan "Hamlet". 


\section{METODE PENELITIAN}

\subsection{Metode Pengumpulan Data}

Teknik yang digunakan dalam pengumpulan data untuk keperluan penelitian adalah sebagai berikut:

a. Wawancara dan observasi, teknik ini digunakan untuk mendapatkan data primer yaitu melalui wawancara dengan petugas perpustakaandi fakultas teknologi informasi dan komunikasi untuk mendapatkan data judul-judul tugas akhir yang sudah tercatat di perpustakaan.

b. Studi pustaka, teknik ini digunakan untuk mendapatkan data sekunder tentang obyek penelitian dan referensi tentang teori pendukung dan metode melalui buku-buku dan majalah ilmiah.

\subsection{MetodePengembangan Sistem}

Metode pengembangan sistem yang digunakan dalam penelitian ini adalah metode prototype. Metode prototype adalah proses dimana permintaan pengguna diubah ke dalam sistem yang bekerja, secara terus menerus diperbaiki melalui kerja sama antara pengguna dan pembuat sistem.

Metode ini sering digunakan dalam pengembangan sistem, karena terdapat interaksi yang baik antara pengguna dan pembuat sistem.

Sering terjadi gap antara pengguna dan pembuat sistem. Dimana pengguna hanya mendefinisikan secara umum apa saja yang dikehendakinya tanpa menyebutkan secara detail, output apa yang dibutuhkan, pemrosesan dan data apa saja yang dibutuhkan, kendala lapangan, dan lain sebagianya. Dan sebaliknya, dari sisi pembuat sistem, kurang memperhatikan kondisi kemampuan pengguna, kondisi lapangan, dan kebutuhan pengguna secara detail.

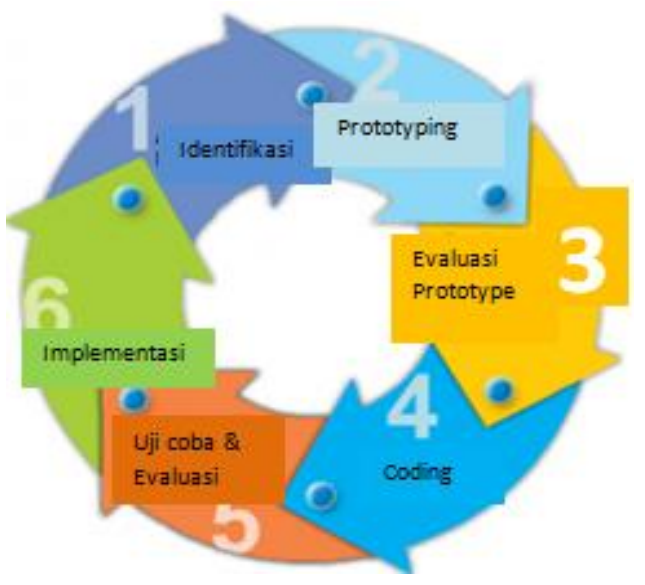

Gambar 2. Model Prototype

Dengan menggunakan metode prototype, pengguna dilibatkan secara aktif dalam proses pengembangan sistem.

Adapun tahap - tahap dalam metode prototype ini adalah sebagai berikut :
1. Identifikasi kebutuhan

Pembuat sistem, bersama sama dengan pengguna mendifinisikan format seluruh perangkat lunak, mengidentifikasikan seluruh kebutuhan, dan garis besar sistem yang akan dibuat.

2. Membangun prototyping

Adalah proses pembuatan rancangan sementara yang berfokus pada penyajian kepada pelanggan.

3. Evaluasi prototyping

Langkah ini melibatkan pengguna. Dimana pengguna akan memberikan penilaian, apakah prototype nya sudah sesuai dengan kebutuhan dan keinginan pelanggan. Jika sudah, maka pembuat sistem akan melanjutkan ke langkah berikutnya. Jika belum, maka akan diulang dari langkah 1,2 dan 3.

4. Coding

Pada tahap ini, setelah semua desain sesuai dengan kebutuhan pengguna, maka akan diterjemahkan ke dalam bahasa pemrograman yang akan dipakai dalam sistem.

5. Menguji Sistem dan Evaluasi

Setelah program bantu jadi, maka diujicobakan pada sistem. Dan diamati apakah sudah sesuai dan sudah dapat mengatasi kebutuhan serta kendala lapangan. Uij coba ini menjadi evaluasi bersama antara pengguna dan pembuat sistem. Jika dirasa masih ada yan kurang sesuai, maka akan diulang dari langkah ke 4. Jika sudah cocok, dilanjutkan dengan tahap ke 6.

6. Implementasi Sistem

Program bantu yang sudah jadi dan diterima oleh pengguna, siap diimplementasikan.

\section{HASIL \& PEMBAHASAN}

\subsection{Data Penelitian}

Dalam penelitian ini data yang peneliti kumpulkan adalah judul-judul Tugas Akhir (TA) dengan stuktur sebagai berikut:

Tabel 2. Struktur judul TA

\begin{tabular}{|l|lr|}
\hline Field & Keterangan & \\
\hline Kategori & $\begin{array}{l}\text { Kategori judul } \\
\text { Akhir/TA,Kerja Praktek/KP) }\end{array}$ \\
\hline Progdi & $\begin{array}{l}\text { Program Studi } \\
\text { Informatika/TI, } \\
\text { Informasi/SI) }\end{array}$ & $\begin{array}{r}\text { (Teknik } \\
\text { Sistem }\end{array}$ \\
\hline Tahun & Tahun TA disahkan & \\
\hline Nama & Nama mahasiswa & \\
\hline Nim & Nim mahasiswa & \\
\hline Judul & Judul TA \\
\hline Pembimbing 1 & Pembimbing 1 TA & \\
\hline Pembimbing 2 & Pembimbing 2 TA \\
\hline
\end{tabular}

Data judul yang peneliti peroleh dari petugas perpustakaan adalah data dari tahun 2007 - 2017 sebanyak 1695 record dengan judul TA dari progdi Teknik Informatika (TI)sebanyak 1272 record dan progdi Sistem Informasi (SI) sebanyak 423 record. Berikut sebaran data judul yang peneliti peroleh. 
Tabel 3. Sebaran data sesuai tahun dan program studi

\begin{tabular}{|c|c|c|}
\hline Tahun Judul & \multicolumn{2}{|c|}{ Program Studi } \\
\cline { 2 - 3 } TA & TI & SI \\
\hline 2007 & 10 & 3 \\
\hline 2008 & 12 & 7 \\
\hline 2009 & 31 & 8 \\
\hline 2010 & 39 & 9 \\
\hline 2011 & 28 & 7 \\
\hline 2012 & 75 & 23 \\
\hline 2013 & 173 & 38 \\
\hline 2014 & 256 & 89 \\
\hline 2015 & 285 & 87 \\
\hline 2016 & 271 & 102 \\
\hline 2017 & 92 & 50 \\
\hline Jumlah & $\mathbf{1 2 7 2}$ & $\mathbf{4 2 3}$ \\
\hline
\end{tabular}

\subsection{Komponen Mesin Pencari}

\subsubsection{Indexing Process}

Indexing process merupakan fungsi utama dalam komponen mesin pencari yang mempunyai fungsi untuk membangun struktur yang memungkinkan untuk pencarian. Indexing process terdiri dari 3 komponen utama yaitu, text acquistition, text transformation, dan index creation.

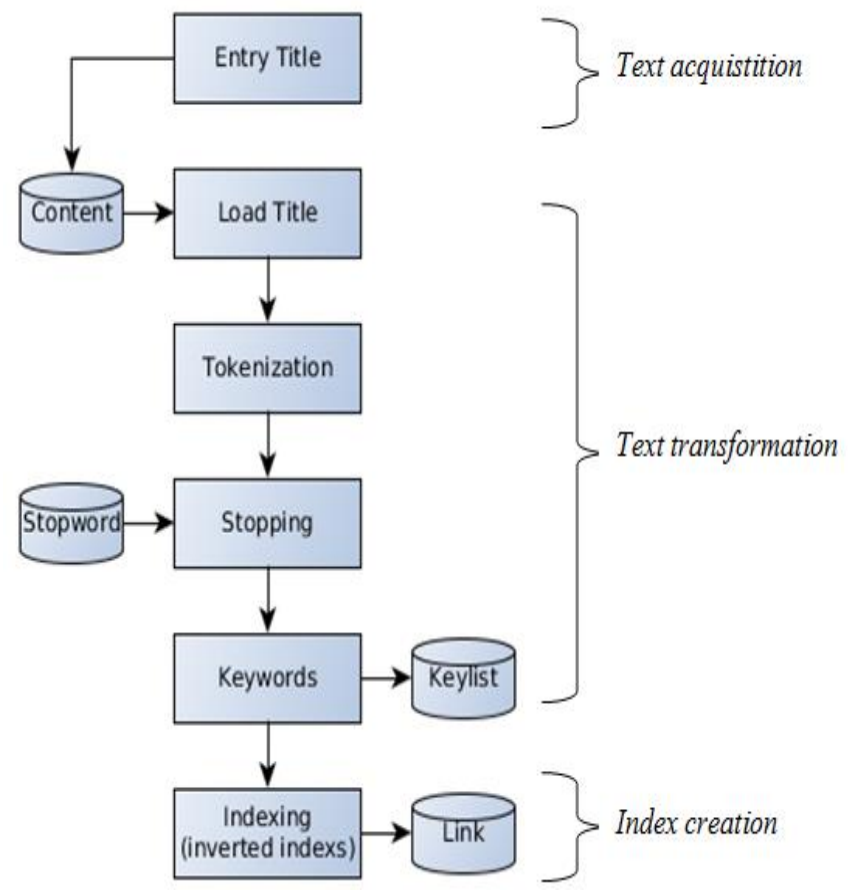

Gambar 3. Alur Indexing Process

\subsubsection{Text Acquisition}

Tugas utama dari text acquistition adalah untuk mengidentifikasi dan membuat dokumen untuk siap dicari. Komponen ini akan lebih sering membangun koleksi berupa document data store pada komputer yang mengandung teks dan metadata untuk semua dokumen.Untuk persiapkan Document data store judul-judul Tugas Akhir dibuat sebuah tabel pada server MySQL dengan struktur sebagai berikut:

$$
\begin{array}{ll}
\text { Nama Tabel } & \text { : Content } \\
\text { Tujuan } & : \text { Untuk menyimpan data-data judul }
\end{array}
$$

Tabel 4. Struktur Tabel Content

\begin{tabular}{|l|l|l|}
\hline Nama Field & Tipe & Keterangan \\
\hline contid & mediumint(9) & Id content \\
\hline prodi & enum('TI', 'SI') & $\begin{array}{l}\text { Nama program } \\
\text { studi }\end{array}$ \\
\hline kategori & enum('TA', 'KP') & Kategori judul \\
\hline tahun & int(4) & Tahun judul \\
\hline nama & varchar(100) & Nama mahasiswa \\
\hline nim & char(13) & Nim mahasiswa \\
\hline judul & varchar(255) & Nama judul \\
\hline pembimbing1 & varchar(100) & Pembimbing ke-1 \\
\hline pembimbing2 & varchar(100) & Pembimbing ke-2 \\
\hline parsing & enum('Y', 'T') & Status parsing \\
\hline
\end{tabular}

Terdapat 2 (dua) metode untuk membuat document data sore judul-judul pada tabel "Content" yaitu:

Import Judul TA ke tabel 'Content' di MySQL Server.

Terdapat 2 (dua) metode untuk membuat document data sore judul-judul pada tabel "Content" yaitu:

Import Judul TA ke tabel 'Content' di MySQL Server. 


\begin{tabular}{|c|c|c|c|c|c|c|c|}
\hline & A & B & $C$ & D & $\mathrm{E}$ & $\mathrm{F}$ & \\
\hline 1 & contid & prodi & kateg & tahun & nama & nim & judul \\
\hline 2 & & $\mathrm{Tl}$ & $\mathrm{TA}$ & 2007 & IANU ARIYANTO WIBOWO & G.211.02.0006 & Pembelajaran Multimedia pengenalan bahan - bahan kimia dalam pro \\
\hline 3 & & $\mathrm{Tl}$ & TA & 2007 & RYFKI MAULANA & G.211.03.0018 & Pemanfaatan Sensor cahaya untuk menghitung jumlah Orang Dalam \\
\hline 4 & & $\mathrm{TI}$ & TA & 2007 & YOSEP AGUNG PRAMUNDAYA & G.241.05.0003 & sistem informasi Administrasi pembayaran sekolah pada SMP MARSU \\
\hline 5 & & $\mathrm{Tl}$ & TA & 2007 & WAHYU IKHA SULISTYANTO & G.211.02.0022 & TUTORIAL PEMBUATAN ANIMASI IKLAN BANNER DENGAN MACROMED \\
\hline 6 & & $\mathrm{Tl}$ & TA & 2007 & Wida Adhi Hapsara & G.211.02.0001 & Pemanfaatan Macromedia Flash sebagai Media Informasi Dalam Peran \\
\hline 7 & & $\mathrm{Tl}$ & TA & 2007 & BUDI SETIAWAN & G.241.05.0016 & sistem informasi CRM (Customer Relationship Management) Berbasis \\
\hline 8 & & $\mathrm{Tl}$ & TA & 2007 & ARI ANDHINI & G.211.02.0011 & Macromedia Flash MX Profesional 2004 Sebagai Sarana Pembelajaran \\
\hline 9 & & $\mathrm{Tl}$ & TA & 2007 & USWATUN HASANAH & G.211.02.0024 & Penggunaan Macromedia flash Mx sebagai sarana pembelajaran Anat \\
\hline 10 & & $\mathrm{Tl}$ & TA & 2007 & EPI NOPIANTI & G.211.02.0023 & pembelajaran pijat refleksi dengan menggunakan BORLAND - DELPHI \\
\hline 11 & & $\mathrm{Tl}$ & TA & 2007 & Galih Septyawan & G.211.02.0007 & Multimedia sebagai sarana pembelajaran Bahasa Inggris Mengenai A \\
\hline 12 & & $\mathrm{Tl}$ & TA & 2008 & CATUR ADI PURNOMO & G.241.05.0009 & UIIAN MASUK MAHASISWA BERBASIS KOMPUTER MENGGUNAKAN MA \\
\hline 13 & & $\mathrm{Tl}$ & TA & 2008 & MUHAMAD AMRULLAH & G.211.02.0016 & Sistem pembelajaran berbasis WEB pada Fkultas Hukum UNIVERSITA \\
\hline 14 & & $\mathrm{Tl}$ & TA & 2008 & UDI HERVIANTO & G.211.03.0023 & Papan Informasi Kehadiran pada Ruang Dekan Fakultas TIK Berbasis \\
\hline 15 & & $\mathrm{Tl}$ & TA & 2008 & HARISANTO ARIF SUBENO & G.241.04.0009 & Sistem Informasi Manajemen Sumber Daya Manusia pada PT. MITRA P \\
\hline 16 & & $\mathrm{Tl}$ & TA & 2008 & Rochmad Adiono Utomo & G.241.05.0017 & penyandian file gambar BMP dengan metode Enkripsi \& DEKRIPSI \\
\hline 17 & & $\mathrm{Tl}$ & TA & 2008 & VIENDA WINTARI & G.241.05.0010 & sistem informasi penggajian karyawan pada SMPN 1 MRANGGEN DEM \\
\hline 18 & & $\mathrm{Tl}$ & TA & 2008 & WISNU ADHI MAHENDRA & G.211.02.0017 & PROGRAM BANTU PELAJARAN PENGENALAN TO BE dalam Bahasa Ingg \\
\hline 19 & & $\mathrm{Tl}$ & TA & 2008 & YUDI PRAMONO & G.211.02.0005 & Game Sibonie berbasis Macromedia Flash untuk Sekolah Dasar \\
\hline 20 & & $\mathrm{Tl}$ & TA & 2008 & BIMO HARYO SETYOKO & G.241.05.0008 & pengendalian penenangan rumah melalui port paralel mengqunakan \\
\hline 21 & & $\mathrm{Tl}$ & TA & 2008 & AHMAD QOHAR WAHYUDDIN & G.211.02.0004 & PENGENALAN KOSAKATA BAHASA INDONESIA, BAHASA INGGRIS, DAN \\
\hline 22 & & $\mathrm{TI}$ & TA & 2008 & ROCHMAD WIBOWO & G.241.05.0005 & Sistem Informasi Keuangan Sekolah di SMA MUHAMMADIYAH SALATIG \\
\hline 23 & & $\mathrm{Tl}$ & TA & 2008 & R Gatot NURHADI Priyono & G.241.05.0013 & Pembelajaran interaktif menarik komputer menggunakan SWISHMAX \\
\hline 24 & & $\mathrm{Tl}$ & TA & 2009 & HAFIS MADYASTA & G.211.03.0006 & Sistem Informasi Geografis Letak SPBU Yang Sudah Terakreditasi ' Pas \\
\hline 25 & & $\mathrm{Tl}$ & TA & 2009 & YAZID RAHMANULLAH & G.231.05.0024 & pembelajaran jaringan komputer mengqunakan Swistimax 2004 \\
\hline
\end{tabular}

Gambar 4. Data judul pada spreadsheet

Data judul-judul diatas kemudian diimport ke dalam tabel untuk membentuk koleksi dokumen judul-judul TA. Gambar di bawah ini merupakan tampilan hasil import ke dalam tabel "Content".

\begin{tabular}{|c|c|c|c|c|c|c|}
\hline contid & prodl & kategori & tahun & nama & $\mathrm{nim}$ & Judul \\
\hline 1 & TI & TA & 2007 & $\begin{array}{l}\text { JANU ARIYANTO } \\
\text { WIBOWO }\end{array}$ & G.211.02.0006 & $\begin{array}{l}\text { Pembelajaran Multimedia pengenalan bahan - bahan } \\
\text { k... }\end{array}$ \\
\hline 2 & $\mathrm{TI}$ & TA & 2007 & RYFKI MAULANA & G.211.03.0018 & $\begin{array}{l}\text { Pemanfaatan Sensor cahaya untuk menghitung } \\
\text { jumlah ... }\end{array}$ \\
\hline 3 & $\mathrm{Tl}$ & TA & 2007 & $\begin{array}{l}\text { YOSEP AGUNG } \\
\text { PRAMUNDAYA }\end{array}$ & G.241.05.0003 & $\begin{array}{l}3 \text { sistem informasi Administrasi pembayaran sekolah } \\
\text { p... }\end{array}$ \\
\hline 4 & $\mathrm{TI}$ & TA & 2007 & $\begin{array}{l}\text { WAHYU IKHA } \\
\text { SULISTYANTO }\end{array}$ & G.211.02.0022 & $\begin{array}{l}\text { TUTORIAL PEMBUATAN ANIMASI IKLAN BANNER } \\
\text { DENGAN MAC... }\end{array}$ \\
\hline 5 & $\mathrm{Tl}$ & TA & 2007 & Wida Adhi Hapsara & G.211.02.0001 & $\begin{array}{l}\text { Pemanfaatan Macromedia Flash sebagai Media } \\
\text { Informa... }\end{array}$ \\
\hline 6 & TI & TA & 2007 & BUDI SETIAWAN & G.241.05.0016 & $\begin{array}{l}\text { sistem informasi CRM (Customer Relationship } \\
\text { Manage... }\end{array}$ \\
\hline 7 & $\mathrm{TI}$ & TA & 2007 & ARI ANDHINI & G.211.02.0011 & $\begin{array}{l}\text { Macromedia Flash MX Profesional } 2004 \text { Sebagai } \\
\text { Saran.... }\end{array}$ \\
\hline 8 & $\mathrm{TI}$ & TA & 2007 & USWATUN HASANAH & G.211.02.0024 & $\begin{array}{l}\text { Penggunaan Macromedia flash Mx sebagai sarana } \\
\text { pemb... }\end{array}$ \\
\hline 9 & $\mathrm{Tl}$ & TA & 2007 & EPI NOPIANTI & G.211.02.0023 & $\begin{array}{l}\text { pembelajaran pijat refleksi dengan menggunakan } \\
\text { BOR... }\end{array}$ \\
\hline 10 & $\mathrm{TI}$ & TA & 2007 & Galih Septyawan & G.211.02.0007 & $\begin{array}{l}\text { Multimedia sebagai sarana pembelajaran Bahasa } \\
\text { Ingg... }\end{array}$ \\
\hline 11 & TI & TA & 2008 & CATUR ADI PURNOMO & G.241.05.0009 & $\begin{array}{l}\text { UJIAN MASUK MAHASISWA BERBASIS } \\
\text { KOMPUTER MENGGUNAKA... }\end{array}$ \\
\hline 12 & $\mathrm{TI}$ & TA & 2008 & MUHAMAD AMRULLAH & G.211.02.0016 & $\begin{array}{l}\text { Sistem pembelajaran berbasis WEB pada Fkultas } \\
\text { Huku... }\end{array}$ \\
\hline
\end{tabular}

Gambar 5. Data judul pada document data store

Input ke tabel melalui halaman input data judul TA pada sistem

Selain membentuk koleksi dokumen judul dengan melakukan import, user juga disediakan sebuah form untuk entri judul seperti gambar di bawah ini.

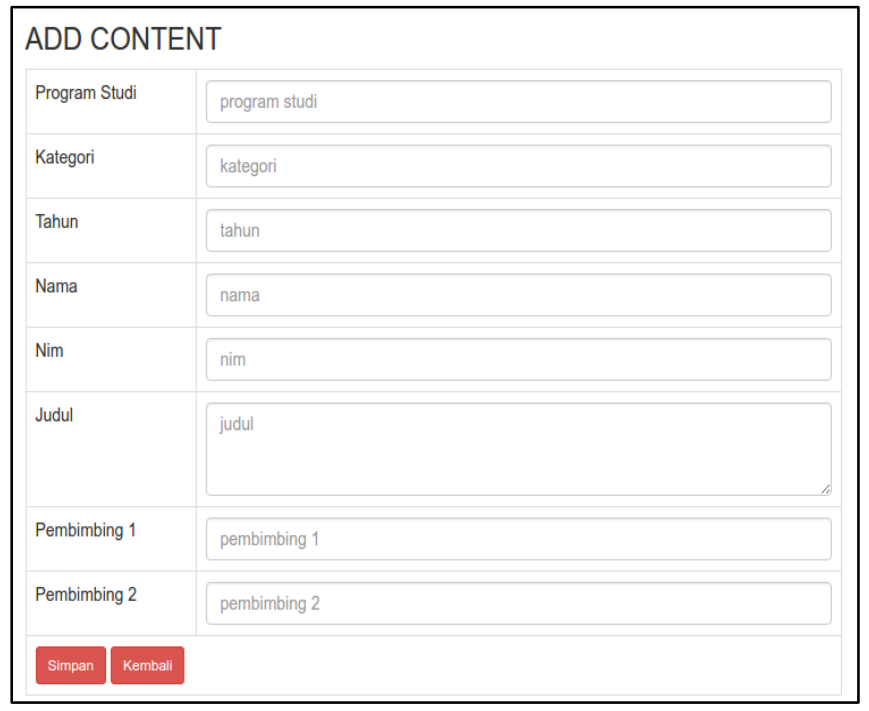

Gambar 6. Form input judul TA

\subsubsection{Text Transformation}

Komponen Text Transformation bertugas untuk merubah kumpulan dokumen ke dalam bentuk index terms berupa kata-kata. Metode yang digunakan adalah Tokenization\& Stoppingyaitu memotong judul menjadi beberapa bagian yang disebut tokendengan menghilangkan kata-kata umum (stop words).Daftar stop words ini disimpan ke dalam tabel "Stopword" yang kemudian digunakan untuk menghilangkan katakata umum pada saat Tokenization. Hasil dari Tokenizationberupa index terms disimpan ke dalam tabel "Keylist". Berikut struktur tabel untuk tahap Text Tranformation. 
a. Stopword

Struktur tabel untuk menyimpan kata-kata umum (kata buangan) yang digunakan sebagai stopword dalam membentuk index terms adalah sebagai berikut:

Nama Tabel : Stopword

Tujuan : Untuk menyimpan kata-kata umum

Tabel 5. Struktur Tabel Stopword

\begin{tabular}{|l|l|l|}
\hline \multicolumn{1}{|c|}{ Nama Field } & \multicolumn{1}{|c|}{ Tipe } & \multicolumn{1}{c|}{ Keterangan } \\
\hline id & $\operatorname{int}(2)$ & Id stopword \\
\hline word & Varchar(255) & Kata umum \\
\hline no & $\operatorname{Int}(1)$ & Jumlah \\
\hline
\end{tabular}

Berikut beberapa kata-kata umum (stopword) yang akan dihilangkan dari judul-judul TA pada proses Tokenizationsesuai dengan Tala (2003):

Keywords (inde terms)

\begin{tabular}{|lllll|}
\hline ada & diantara & Melalui & pun & para \\
adanya & apa & Terlalu & mau & pasti \\
adalah & apaan & Lama & maupun & pastilah \\
adapun & mengapa & Lamanya & semaunya & per \\
agak & apabila & selama & memang & pernah \\
agaknya & apakah & selama- & mereka & pula \\
& & lamanya & & \\
agar & apalagi & selamanya & merekalah & $\ldots$ \\
\hline
\end{tabular}

Struktur tabel untuk menyimpan keyword hasil tokenization adalah sebagai berikut:

$\begin{array}{ll}\text { Nama Tabel } & \text { : Keylist } \\ \text { Tujuan } & \text { : Untuk menyimpan keyword }\end{array}$

Tabel 6. Struktur Tabel Content

\begin{tabular}{|l|l|l|}
\hline Nama Field & \multicolumn{1}{c|}{ Tipe } & \multicolumn{1}{c|}{ Keterangan } \\
\hline Keyed & mediumint(9) & Id key \\
\hline keyword & varchar(100) & keyword \\
\hline
\end{tabular}

Contoh proses text transformation

Judul TA:sistem informasi penggajian karyawan pada SMPN 1 MRANGGEN DEMAK dengan menggunakan Visual Basic 6.0

\begin{tabular}{|l|lr|l|}
\hline Tahap & Tahap & Tahap & Takenization \\
\cline { 1 - 2 } sistem & Stopping & & keywords \\
informasi & sistem & sistem \\
penggajian & informasi & informasi \\
karyawan & penggajian & penggajian \\
pada & karyawan & karyawan \\
smpn & pada & smpn \\
1 & smpn & mranggen \\
mranggen & $\mathbf{1}$ & demak \\
\hline
\end{tabular}

\begin{tabular}{|l|l|l|}
\hline demak & demak & basic \\
dengan & dengan & \\
menggunakan & menggunakan & \\
visual & visual & \\
basic & basic & \\
6.0 & $\mathbf{6 . 0}$ & \\
\hline
\end{tabular}

\subsubsection{Query Process}

Query process tersusun dari komponen user interface yang menyediakan antarmuka antara sesorang yang melakukan pencarian dan mesin pencari. Salah satu tugas utamanya adalah menerima query pengguna dan menerjemahkannya ke dalam bentuk index terms (keyword). Komponen ini terdiri dari Query input, Query transformation dan Results Output.

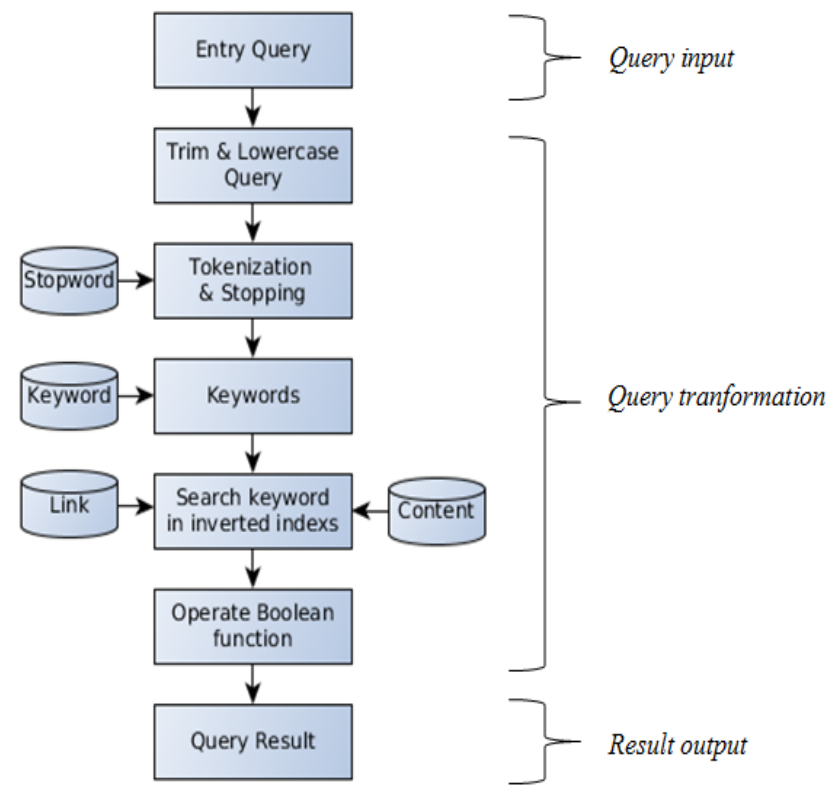

Gambar 7. Alur Querying Process

\section{b. Query input}

Komponen query input menyediakan antarmuka dan parser untuk query. Untuk melakukan pencarian user mengakses halaman pencarian judul kemudian memasukkan kata kunci dan memilih operator Boolean (AND atau OR).

\section{PENCARIAN JUDUL}

Kombinasi kata kunci dengan fungsi Boolean AND dan OR ( contoh : Agent AND System, Agent OR System)

KATA KUNCI : kata kunci

OR V kata kunci 2

\section{Gambar 8. Halaman pencarian}

\section{c. Query Transformation}

Komponen query transformation menggunakan proses sederhana yang melibatkan metode pemrosesan teks untuk mentransformasi query menjadi keywordkeyword yang kemudian dibandingkan dengan indeks 
(inverted indexs) kemudian menerapkan operator Boolean untuk memperoleh hasil pencarian. Metode yang digunakan adalah tokenization dan stopping pada query sedangkanoperator Boolean yang digunaan adalah AND dan OR.

\section{d. Result Output}

Komponen results output bertanggungjawab untuk membentuk tampilan hasil pencarian. Setelah pencarian menemukan judul atau dokumen yang sesuai dengan query, halaman hasil ditampilkan dengan informasi sebagai berikut:

1. Jumlah judul yang ditemukan,

2. Judul-judul yang ditemukan

3. Jumlah referensi kata kunci yang ditemukan pada setiap judul

4. Informasi detil setiap judul

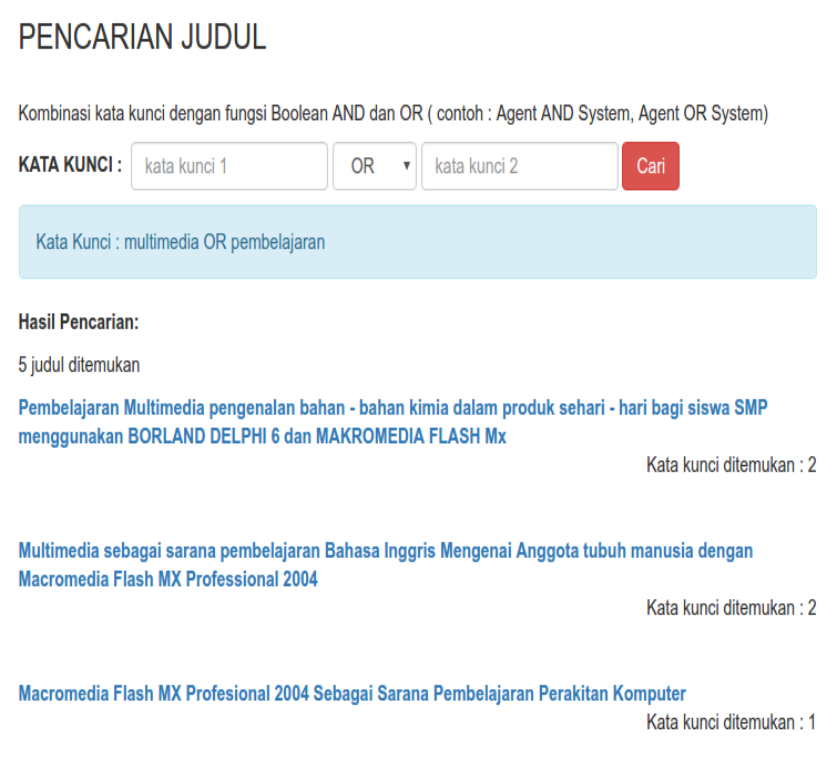

Gambar 9. Halaman hasil pencarian

Untuk mengetahui informasi detil tiap judul yang ditemukan, pengguna dapat melakukan klik pada judul yang kemudian akan muncul halaman berikut ini.

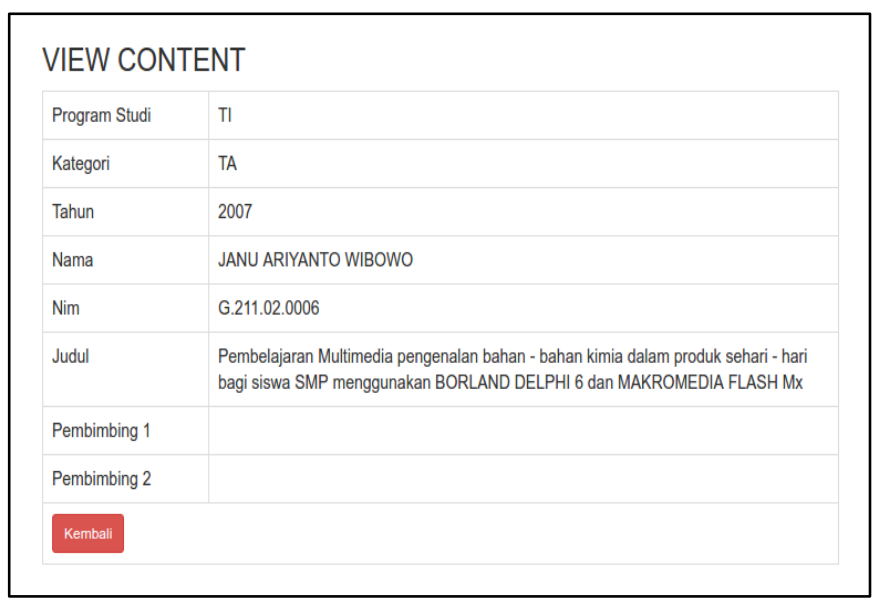

Gambar 10. Halaman detil hasil pencarian

\subsubsection{Pengujian dan Pengukuran}

Pengujian dilakukan dengan mencari judul dengan kata kunci "sistem AND informasi" pada koleksi dokumen dengan jumlah 32 dokumen yang terdiri dari 13 dokumen judul tahun 2007 dan 19 dokumen judul tahun 2008. Hasil dari pencarian ditemukan 11 judul sebagai berikut.

Kata Kunci : sistem AND informasi

Hasil Pencarian: 11 judul ditemukan

1 sistem informasi Administrasi pembayaran sekolah pada SMP MARSUDIRINI MARIA GORETTI SEMARANG

Kata kunci ditemukan : 2

2 sistem informasi CRM (Customer Relationship Management) Berbasis web pada PT. AIMS PERDANA

Kata kunci ditemukan : 2

3 sistem Informasi Penjualan baju dan accessoies secara online pada DISTRO TREESECOND SEMARANG

Kata kunci ditemukan : 2

4 Sistem Informasi Simpan Pinjam pada Koperasi JITU ARTHA PRATAMA dengan Menggunakan Pendekatan Relational Database dan Bahasa Pemrograman Visual Borland Delphi 6.0

Kata kunci ditemukan : 2

5 Sistem Informasi Manajemen Sumber Daya Manusia pada PT. MITRA PENGUSAHA INDONESIA

Kata kunci ditemukan : 2

6 sistem informasi penggajian karyawan pada SMPN 1 MRANGGEN DEMAK dengan menggunakan Visual Basic 6.0

Kata kunci ditemukan : 2

7 Sistem Informasi Keuangan Sekolah di SMA MUHAMMADIYAH SALATIGA dengan VISUAL BASIC VERSI 6.

Kata kunci ditemukan : 2

8 Sistem Informasi Eksekutif Penjualan Menggunakan Visual Foxpro 9.0 ( Studi Kasus PT. Elnusa Petrofin Semarang )

Kata kunci ditemukan : 2

9 Sistem Informasi rawat jalan pasien pada poliklinik umum NUGRAHA SEMARANG dengan menggunkan VISUAL FOXPRO 9.0

Kata kunci ditemukan : 2

10 Sistem Informasi perpustakaan pada SMA N 14 Semarang dengan menggunakan Visual Fox Pro 9.0 Kata kunci ditemukan : 2

11 Sistem Informasi penjualan benang sitetik berbasis WEB pada PT. POLYSINDO EKA PERKASA KALIWUNGU

Kata kunci ditemukan : 2

Judul yang relevan sesuai keinginan pengguna adalah nomor $2,3,4,5,8,9,11$ 
$\underline{\text { Pengukuran hasil pencarian }}$

\begin{tabular}{|l|c|c|c|}
\hline & Relevant & $\begin{array}{c}\text { Not } \\
\text { Relevant }\end{array}$ & Total \\
\hline Retrieved & $8(\mathrm{~A})$ & $3(\mathrm{~B})$ & 11 \\
\hline Not Retrieved & $0(\mathrm{C})$ & $21(\mathrm{D})$ & 21 \\
\hline Total & 8 & 24 & 32 \\
\hline
\end{tabular}

Keterangan:

Koleksi: $\mathrm{A}+\mathrm{B}+\mathrm{C}+\mathrm{D}=32$

Jml Relevan: $\mathrm{A}+\mathrm{C}=8$

Jml Tidak Relevan: $\mathrm{B}+\mathrm{D}=21$

Jml Terpilih: $\mathrm{A}+\mathrm{B}=11$

Jml tidak terpilih: $\mathrm{C}+\mathrm{D}=21$

Maka:

Precision $=\mathrm{A} /(\mathrm{A}+\mathrm{B})=8 /(8+3)=72,73(100 \%)$

Recall $=\mathrm{A} /(\mathrm{A}+\mathrm{C})=8 /(8+0)=100(100 \%)$

$\mathrm{F} 1=2 \mathrm{rp} /(\mathrm{r}+\mathrm{p})=(2 \times 72,73 \times 100) /(72,73+100)=$ $14,546 / 172,73$

$=84,21 \%$

\section{SimpUlan DAN SARAN}

\section{a. Kesimpulan}

Berdasarkan hasil dari tahapan-tahapan dalam penelitian ini dapat diambil kesimpulan sebagai berikut:

1. Implementasi temu kembali informasi pada mesin pencari judul Tugas Akhir dapat memberikan hasil pencarian yang sesuai dengan kata kunci dari pengguna dengan nilai Precision sebesar $72,73 \%$, Recall sebesar $100 \%$ dan nilai gabungan F1 (precision dan recall) sebesar $84,21 \%$.

2. Model penemuan kembali informasi menggunakan Boolean retrieval (AND dan OR) dapat memberikan hasil pencarian yang lebih khusus sesuai dengan operator Boolean yang dipilih.

\section{b. Saran}

Hasil penelitian ini masih memiliki beberapa kekurangan, untuk itu peneliti memberikan saran untuk penelitian selanjutnya sebagai berikut:

1. Penerapan operator NOT pada model penemuan kembali informasi menggunakan Boolean retrieval.

2. Penggunaan model Boolean retrieval dapat dikembangkan ke penggunaan operator Boolean pada query yang bertingkat.

\section{DAFTAR PUSTAKA}

Christioko, B.V. . 2012. Implementasi Sistem Temu Kembali Informasi Studi Kasus: Dokumen Teks Berbahasa Indonesia. Transformatika,10(1), $1-10$.

Croft, W.B., Metzler, D., \& Strohman, T.. 2015. Search Engines Information Retrieval in Practice. USA: Pearson Education, Inc.

Jansen, B. J. and Rieh, S. 2010. The Seventeen Theoretical Constructs of Information Searching and Information Retrieval. Journal of the American Society for Information Sciences and Technology, 61(8), 1517-1534.

Manning, C. D., Raghavan P., \& Schütze H. 2009. An Introduction to Information Retrieval. England: Cambridge University Press.

Mulyana. 2010. Pencegahan Tindak Plagiarisme Dalam Penulisan Skripsi Upaya Memperkuat Pembentukan Karakter di Dunia Akademik. Cakrawala Pendidikan, XXIX, Edisi Khusus Dies Natalis UNY.

Sommerville, Ian. 2011. Software Engineering 9ed. USA: Pearson Education, Inc.

Tala, F.Z. 2003.A Study of Stemming Effects on InformationRetrieval in Bahasa Indonesia.Tesis Master of Logic Project.Universiteit van AmsterdamThe Netherlands 